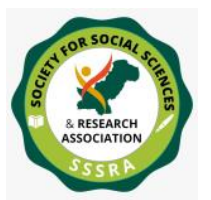

Pak. Journal of Int'L Affairs, Vol 4, Issue 4 (2021) Communism- An Incomplete, Yet Unforgettable ...

\title{
COMMUNISM- AN INCOMPLETE, YET UNFORGETTABLE TALE: A CASE STUDY OF PAKISTAN
}

\author{
Nawal Aamir Khan \\ Student B.S (Economics) \\ Institute of Business Administration (IBA) \\ Karachi-Pakistan \\ nawal-aamirkhan@hotmail.com \\ Samreen Bari Aamir \\ Lecturer \\ DHA Suffa University \\ Karachi-Pakistan \\ paesthetics@yahoo.com \\ Mustafa Raza \\ Senior Lecturer \\ DHA Suffa University \\ Karachi - Pakistan \\ Mustafaraza44@gmail.com
}

\begin{abstract}
The origins of socialism and left-wing ideology in Pakistan can be traced back to the Russian revolution in the early 1900s. In the early twentieth century, the peasants of the Punjab and Sindh, sub-continent's two regions began openly rising against British Empire, while labor unions and strikes popped up in these regions. During the 1930s and early 1940s, the CPI and communism faced numerous challenges. CPI' quickly gained both momentum popularity in the subcontinent posed a severe danger to imperialists, prompting its prohibition in 1934. This restriction, however, had no effect on communism's expanding influence, since communism continued to work under other umbrella organizations. The bourgeois controlled the state in Pakistan at this time, but the proletariat tried to controll the country as a whole. Peasants, workers, and students were all united in their opposition to the regime, while leftists slept soundly, dreaming of the two-stage theory and the democratic revolution that the progressive bourgeois was supposed to bring about.
\end{abstract}




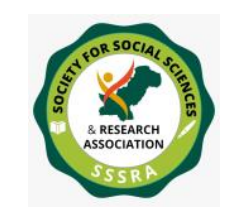

Pak. Journal of Int'L Affairs, Vol 4, Issue 4 (2021) Communism- An Incomplete, Yet Unforgettable ...

Key Words: Socialism, left-wing Pakistan Bourgeois, Proletariat

\section{Research Questions}

1. To trace the origin of socialism and left-wing ideology in South Asia

2. What has been a major obstacle to Communist growth in Central Asia?

3. To study the Impact of Communism on Pakistan.

\section{Research Methodology}

${ }^{\mathrm{i}} \mathrm{We}$ have used the qualitative research method to understand the different aspects and consequences of communism in South Asia before partition and especially on Pakistan after independence. In this study secondary data are used to enrich the article. Sources of secondary data include books, personal sources, journals, newspapers, websites, government records etc.

\section{Introduction}

The existence of socialism and left-wing ideology in Pakistan can be traced back to the early 1900s during the Russian revolution. Along with the rest of the world, Indian subcontinent too drew its fair share of influence from the Russian revolution of 1905 and 1917. Karl Marx saw the 1857 war of independence as a version of the revolt envisioned by him in which the proletariat would stand up against the bourgeoisie. During this time, he wrote several essays on the Indian sub-continent, calling India "an Italy of Asiatic dimensions" and "Ceylon for the island of Sicily" (Marx 2019) (New-York Daily Tribune 1857). The war of independence ended in defeat for the Indians, solidifying British rule and commencing an era of mass exploitation, plunder and oppression.

The people of sub-continent experienced all sorts of perils of colonialism and imperialism. The farmers and unskilled workers were exploited to the fullest, sub-continent was drained of all its resources, children were brainwashed to appreciate the British rule in schools, and the people were even robbed off their cultures. On the whole, the economy of Britain flourished at the expense of the lives of the Indian people, plunging them into more poverty and slavery than they had ever lived in. Moreover, a selected few of aristocrats of India remained favored the colonialists, and managed to garner even more wealth by pleasing them. This resulted in great resistance from the peasantry of the country, which was now a majority, giving birth to a vast proletariat.

The peasants of Punjab and Sindh, had started openly revolting against the British imperialism in the early $20^{\text {th }}$ century, while trade unions and strikes had also sprang all 


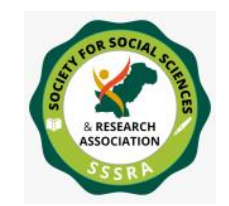

Pak. Journal of Int'L Affairs, Vol 4, Issue 4 (2021) Communism- An Incomplete, Yet Unforgettable ...

over India. The Communist Party of India (CPI) was formed in 1920 and its leader M. N. Roy (CHOUDHARY 2019) participated in the meetings of Third international Conference. The first manifesto of the CPI was drafted in 1921. It declared: If the Congress would lead the revolution, which is shaking India to the very foundation, let it not put faith in mere demonstrations and wild temporary enthusiasm. Let it make the immediate demands of the Trade Unions its own demands; let it make the programme of the Kisan sabhas (Peasant Unions) its own programme; and the time will soon come when the Congress will not stop before any obstacle; it will be backed by the irresistible strength of the entire population consciously fighting for the material interest. (75th Anniversary of the Formation of the Communist Party of India 1984).

\section{The Peshawar Conspiracy Cases}

Against the background of the Hijrat (Migration) Movement, the Peshawar conspiracy cases of the 1920s emerged. Many self-exiled Muslims, calling themselves Muhajirs, migrated to neighboring countries i.e., Afghanistan and Turkey, deeming it not fit for a land for Muslims to live in. When they were not allowed to enter Turkey, many of them went to Tashkent. After the Bukharan revolution, all muhajireen were gathered in Bukhara to meet N. M. Roy. Here, they were offered by Roy to accompany him to Tashkent where they could train and study to fight for the independence of India. Half of the people decided to return to India while the other half wanted to proceed to Turkey. The latter were helped to reach Turkey but were refused visas by the Turkish government.

The first batch of muhajireen reached Peshawar on June 3, 1921, where they were interrogated by Mr Ewart, the office-in-charge of India's intelligence bureau. This is when the British learned about the group of forty people who accompanied Roy to Tashkent and twenty-six of them were identified to have joined political and military schools and had later gone to Moscow for further training at the Communist university for Toilers in the East. (Ahmed 2016) . Keeping a watch out on those who had gone to Tashkent and later Moscow for training, the British-Indian police carried out many arrests in 1922. Hence, the Peshawar conspiracy cases emerged where twelve to thirteen people received barbarous jail sentences. The muhajireen who had joined the CPI decided to return to India after their training was completed in Tashkent and Moscow. Ten were sent to work underground but seven of them of them got arrested and were sent to Peshawar under Police guard. The Peshawar conspiracy cases greatly impacted the freedom movement, setting the tone of future struggle for liberation and established communists as important players in Indian politics.

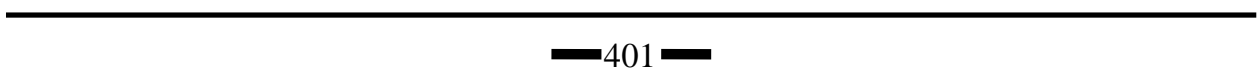




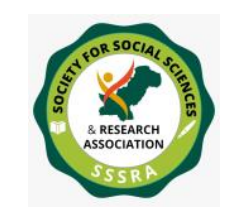

Pak. Journal of Int'L Affairs, Vol 4, Issue 4 (2021) Communism- An Incomplete, Yet Unforgettable ...

\section{0-47}

The CPI and communism faced many trials and tribulations during 1930s and early 1940s. The rapidly spreading popularity of CPI in India was a serious threat to imperialists, leading to its ban in 1934. This ban, however, did not halt the growing influence of communism, as communists continued to work incessantly under other umbrella organizations.

On the other hand, the Third International Conference during Stalin's regime had gone through a time of degeneration. Betraying the Indian Proletariat, the CPI opposed the second world war only until Stalin had not signed a peace treaty with the British, and refused to fight against British imperialism because Stalin was now an ally of Britain and India had not gone through the bourgeois democratic revolution according to the two stage theory (Shukla 1997). Meanwhile, millions of young revolutionaries and freedom fighters, disregarded as 'fifth columnists' (Karat November, 2019) by the CPI, valiantly fought against British imperialism; they were flogged, imprisoned and killed but led their countrymen to openly revolt against the colonizers by 1946 .

In 1946, the year of revolution, mass uprisings and strikes took place; navy sailors went on strike, workers of the Royal Air force revolted, sepoys and policemen revolted in many cities, and workers of railway and many industries also joined the uprising. The CPI, instead of supporting the revolt of the proletariat, opposed them, in hopes of a bourgeois revolution which never came, and supported British imperialism, completely alienating itself from the working class of the subcontinent. The CPI supported partition in August 1947, and ordered its cadres to migrate to Pakistan after it (Ahmed, I. (2010). The rise and fall of the Left and the Maoist movements in Pakistan. n.d.).

\section{AFTER PARTITION}

After independence, Muslim League became main stakeholder of politics in Pakistan. It was dominated by aristocrats and feudal lords as, essentially, it was their creation. The Communist Party of Pakistan (CPI) which inherited both members and ideologies from CPI, joined the Muslim League and distinguished between its members by categorizing them into feudals and bourgeoisie, supporting the latter. Nevertheless, the power of the feudals was such that they completely purged the Muslim league of CPP by labelling them as infiltrators, to which the CPP responded by planning a coup rather than organizing the working class for a revolution. 


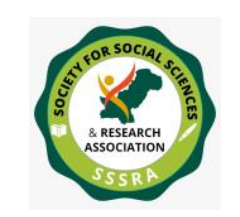

Pak. Journal of Int'L Affairs, Vol 4, Issue 4 (2021) Communism- An Incomplete, Yet Unforgettable ...

\section{The Rawalpindi Conspiracy Case}

The CPP was being tremendously persecuted by the Pakistani government in this time period. Their leaders were arrested, their sympathizers were brutally beaten and interrogated, and all their workers were forced to go underground. Meanwhile, Major General Akbar Khan, the Chief of General Staff, developed grudges against the government chief in control, General Douglas Gracey, for putting a brake on further involvement of the military in Kashmir. Akbar Khan's belief that a continued armed struggle on the border could have brought Pakistan close to the Kashmir, and frustration for not being able to do this, led him to conjure up the plan of a coup d'etat with the CPP (Rahim 2019).

Major Akbar and his wife, Begum Nasim, were careless with their excessive criticism of the government which alerted the intelligence agencies to the extent that they were under constant surveillance. Akbar promised the CPP power and political freedom, while he also lured common people and other civilians with eradication of corruption and nepotism, land reforms and discourse on Kashmir. He met with some other military generals and civilians including Faiz Ahmed Faiz (POET.ORG n.d.) and Sajjad Zaheer (Jalil 2018) to discuss these plans and garner more support. The plan was to arrest Khwaja Nazimuddin and Liaquat Ali Khan when they were to be in Rawalpindi but was leaked by Akbar's confidant, Askar Ai Shah, a Police Officer, to the IG and then the governor of NWFP who took no time to take action and informed the Prime Minister Liaquat Ali Khan.

Major Akbar Khan, his wife Naseem Akbar, Brigadier Latif Khan, Faiz Ahmed Faiz, and Muhammad Hssan Ata (a member of the central committee of CPP) including others, were arrested, tried, found guilty and (except Naseem Akbar) were imprisoned for a number of years. The CPP's participation in this attempted coup proved to be disastrous for any sort of a Marxist or socialist revolution in the country, which has led many historians to speculate if there was a level of US involvement in the whole matter (The Rawalpindi Conspiracy Case: Myth or Reality - An Analysis 2006).

\section{0s-1960s and the Sino-Soviet Conflict}

The Communist party also took part in the language movement in East Pakistan and joined labour strikes as well, establishing itself as a force against zamindaars (feudals). They also managed to form a democratic government in East Pakistan with the support from Awami league but were banned due to their increasing scuffles with the East Pakistani police. Following the Rawalpindi Conspiracy case and this episode, the CPP, along with its student and trade union wings, was banned. Its members, subsequently, formed the Azad 


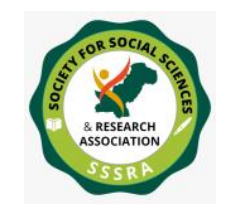

Pak. Journal of Int'L Affairs, Vol 4, Issue 4 (2021) Communism- An Incomplete, Yet Unforgettable ...

Pakistan Party, and later in 1957, merged with other progressive liberal groups to form the National Awami Party (NAP). The Communists ceased to identify independently or through a political platform such as that of the NAP, not taking part in any reform for a worker's revolution as well. However, there was a rise in the growth of agitation and resentment among the working class and peasantry which led to the country being gripped by a working class revolution. Threatened by the growing resentment among the people, General Ayub Khan imposed a martial law in October, 1958 (Maniruzzaman 1971).

A major reason for the Pakistani left not being successful was the impotent two-stage theory of Stalin which resulted in a tilt towards Maoism in later years. The Chinese revolution in 1949 had been successful in defeating feudalism and capitalism, and greatly attracted many colonial countries, but due to a shared border with Pakistan, particularly intrigued the working class, students and academics of Pakistan. Despite the apparent flawlessness of Maoism and the Chinese Revolution, its bureaucratic deformations became visible when China fiercely supported the government of Ayub Khan, whose era was defined by its empowering of the bourgeoisie. When war broke out between India and Pakistan, China supported Pakistan further strengthening its ties with the Military government. Pakistani Maoists also supported Ayub, his foreign policy, and his economic policies.

Meanwhile, the Soviet Union had been supporting India in the war in order to rid it of Western influence. Hence, the Pakistani left found itself divided in two wings: the proMoscow left which supported one faction of the bourgeoisie, deeming it as progressive, and the Pro-Beijing left which supported another faction of the bourgeoisie, deeming it as progressive. The left wing of this time failed to appeal to the masses. Their sole aim had become to gain support from different sections of the bourgeois for their movement and used the proletariat only for sloganeering, ignoring the boost in capitalism which had created an explosive proletariat movement even Ayub Khan could not withstand.

A hike in the price of sugar is what initiated the movement as students took part in the protests against it. The spark which set the whole forest ablaze, however, proved to be the killing of a student of the Rawalpindi polytechnic college, Abdul Hameed. This amalgamated the whole proletariat of Pakistan into one fierce revolutionary movement. Railway workers were the first ones to go on strike in 1967, ignoring the discouragement from their legal union and illegal union (controlled by communists) who continued to support Ayub Khan. Strike committees were formed, the peasantry rose against their feudal lords, workers took over all factories, mills and industries, all forms of censorship was sorely defeated, trains; trucks and many more new means of communication were invented to propagate the message of a revolution (TFT 2019). 


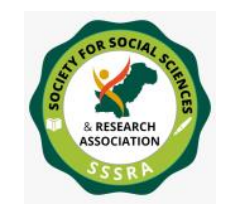

Pak. Journal of Int'L Affairs, Vol 4, Issue 4 (2021) Communism- An Incomplete, Yet Unforgettable ...

At this point in Pakistan, the state was in control of the bourgeois but the entire country had fallen in the hands of the proletariat. Peasants, workers, and students were all united in their revolt against the government, while the leftists remained in slumber, still dreaming of the two-stage theory and the democratic revolution which had to be brought about the progressive bourgeois according to it.

\section{0s and the Pakistan People's Party}

The Pakistan People's Party, a party with a radically socialist ideology was formed on September $1^{\text {st }}, 1967$. Its manifesto was written by a communist, J. A. Rahim, and its frontman appeared to be Zulfiqar Ali Bhutto, another politician with leftist ideologies who declared the PPP's beliefs in the following words,

"Islam is our faith, democracy is our policy, and socialism is our economy. All power to the people (Mariam Mufti 2020)."

Z. A. Bhutto was a feudal lord from Sindh and a very intelligent bourgeois politician, who held important minis been a Foreign Minister for Ayub Khan as well, used the socialist slogan 'Roti Kapra Makan' (Bread, Clothing and shelter) to harmonize the masses in Pakistan. When he formed the PPP, the government started targeted him which established him as a symbol of resistance against tyranny, and exponentially increased his popularity in both the PPP and the country. While the Maoists and Stalinists continued to support Ayub Khan, it was Bhutto who, despite being a feudal, used socialist sloganeering to make PPP a party of the working class and himself, a representative of the working class.

It was the revolutionary movement of 1968-69 which had subsequently led to the popularity of the PPP, as many labour leaders along with the masses joined the party in hopes of a change that could be brought about through socialism. Moreover, parties with socialist manifestos have had greater influence in countries with a colonial past due to which the leftists of Pakistan also eventually joined the PPP, reconciling with feudal bourgeois and capitalists. However, the fact that the PPP was only radically socialist in its slogans, but was essentially feudal and capitalistic due to being organized on a bourgeois democratic basis, was proven after its unprecedented right-wing turn.

After coming to power, Bhutto managed to bring about some major changes through land reforms, nationalization, and other reforms in education, health etc. In 1972, forty-three large industrial units like fertilizers, oil refinery, and chemicals were nationalized; whereas three years later cooking oil industries, flour milling, cotton ginning, and rice husking mills were also nationalized (W. James 1992). While the former affected monopoly capitalists, 


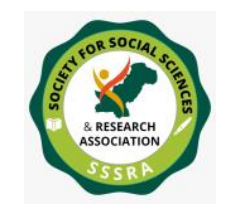

Pak. Journal of Int'L Affairs, Vol 4, Issue 4 (2021) Communism- An Incomplete, Yet Unforgettable ...

the latter severely impacted small business owners and entrepreneurs, dissolving all hopes of greater equity to be achieved through nationalization. Instead, Bhutto's policies only expanded the state's resources to enable it to practice a traditional form of power through state patronage.

Since 1973, the PPP which drew its power from the working and middle class completely purged their presence in the party, continuing with the tradition of total domination of feudalism over politics. Higher inflation rates, withdrawal of subsidies on consumption goods and the falling real income of the middle and working class heightened the agitation and resentment among common people who had big hopes from Bhutto's so-called socialist reforms. The swarming sea of people with anti-bourgeois sentiments who had dethroned Ayub and handed Bhutto his regime now took the streets to demonstrate against him, leading to his downfall.

\section{0s- Military Dictatorship}

Ultimately, it was military dictatorship which got rid of Bhutto. The left failed to produce any alternative during Bhutto's decline which paved the way for religious extremism and right-wing reactionary politics. Zia ul Haq, the new president was a staunch rightist and religious fanatic who dealt with socialists, Marxists and communists with extreme political oppression, throwing many of them in jails or adding them to the list of hundreds of missing persons of that time.

After Bhutto's hanging through a phony trial in 1979, the popularity of PPP reignited as it regained its position of the strongest resisting force against military dictatorship. The Movement for Restoration of Democracy (MRD) united the PPP right wing, liberals and leftists against dictatorship but the left, at this point, constrained itself to social democratic demands only. By this time the Communist party (Pro Moscow Stalinist), Worker's Peasant Party (Maoist) and Socialist Party (Stalinist) had gained substantial support from different areas but were unable to launch an independent and organized struggle. Meanwhile, the Zia regime intensified its oppression in NWFP, Sindh and Baluchistan.

In 1986, all pro-Moscow groups; Pakistan National Party, MKP, National Democratic Party, and Awami Tehreek merged together to form the Awami National Party- another socialist party with bourgeois nationalists as its main leaders which the National Democratic Party, Awami Tehreek, and MKP soon disassociated themselves from. The Qaumi Inqilaabi Party was formed after mergers between different leftist and bourgeois nationalist parties in 1987 only to be disbanded a year later. In 1988, Qaumi Mahaz-eAzadi (National Liberation Front), a Maoist party, and the Workers Party (a Stalinist party) 


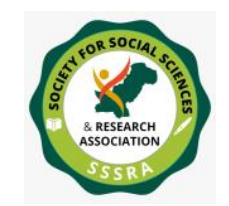

Pak. Journal of Int'L Affairs, Vol 4, Issue 4 (2021) Communism- An Incomplete, Yet Unforgettable ...

merged to form AJP (Awami Jomhori Party -- People's Democratic Party), but barely a few months had passed when, on the eve of an election, the merger was split. The National Liberation Front, led by Meraj Mohammad Khan, left the party. The issue was whether AJP should support Benazir or Nawaz Sharif.

Subsequently, a group of activists calling themselves supporters of the monthly Mazdoor Jeddojuhd (Workers Struggle) entered the leftist politics of Pakistan in 1986. The struggle group was formed in 1980 and had been working with the PPP since then for the restoration of democracy in Pakistan as PPP had again managed to disillusion the masses into believing it was going to save the working class from the plight of Zia's regime. The leaders of this struggle group returned to Pakistan from exile to intensify their efforts against dictatorship.

The Jeddojuhd magazine soon developed a cult status in Pakistan as many revolutionary socialist poets like Habib Jalib, Ahmed Faraz, and Faiz Ahmed Faiz (although Faiz died in 1984) contributed to it with their anti-dictatorship Urdu poetry.

The magazine published Habib Jalib poem, 'Main Baaghi Hoon' (I am a rebel) in 1984 which became a staple in popular culture due its revolutionary tone and was used in underground protests against Zia.

\section{8-Present}

Zia ul Haq died in an airplane crash in August 1988, after his demise, general elections were held and PPP, under the leadership of Benazir Bhutto, came to power. Benazir turned out to be another harbinger of false hope for the middle class and working class. However, it was the collapse of the Soviet which actually broke the back of the Pakistani left. The break-up of the USSR was a major set-back to leftists all around the world as Stalinists all around the world, including Pakistan, shifted towards social democracy. The 1990s in Pakistan became a period in which fundamentalism and counter-revolutionary consciousness started rising in Pakistan.

Despite the hopelessness, the struggle group remained steadfast in its faith in socialism and parted its ways with the PPP to create an alternative movement, the Jeddojuhd Inqilaabi Tehreek in 1993. This movement worked towards launching a successful worker's revolution though trade unions and was successful in forming the Labour Party of Pakistan. In 1994, the Communist Party and MKP also merged together for a stronger standing. In 1999, three more parties- AJP, Pakistan National Party and Socialist Party - merged to 


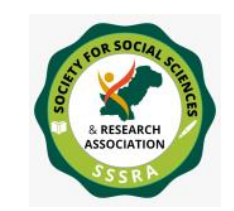

Pak. Journal of Int'L Affairs, Vol 4, Issue 4 (2021) Communism- An Incomplete, Yet Unforgettable ...

form the National Workers Party (NWP). Both CMKP and NWP still believe in a bourgeois democratic program, while NWP is turning more and more to the right.

As an aftermath of 9/11 and US invasion of Afghanistan, socialism and conservatism started rising there. Whereas in Pakistan, liberals came into powe for the first time in 2002. The new president, Pervaiz Musharraf introduced the ideas of the Third way and Enlightened Moderation which attempted to bring the right and left wing together, but still faced resistance. After the assassination of Benazir Bhutto in December 2007, the left further lost its steer as there was a rapid insurgency in right-wing politics and fundamentalism. At present the LPP, CMKP and NWP are the three main parties. Besides these three, there are some left groups having little influence. None of the left parties has a mass base. The left cannot at all be seen as a powerful force in Pakistan at the moment. However, the LPP has achieved some success since its formation in gaining a semi-mass base, especially in Sindh. The huge gap existing in left is currently being filled by the LPP.

\section{Conclusion}

The left orientation has greatly influenced the literature, scientific activities, arts, and popular culture of Pakistan. The literary work of Faiz Ahmad Faiz, Sibt e Hassan, Ali Abbas Jallapuri, Habib Jalib and Aitzaz Ahsan have been instrumental in projecting the left-wing ideas in the country. Nevertheless, the lack of economic capability or infrastructure which could make Pakistan self-reliant has prevented socialism to be institutionalized here. Moreover, the opposition from right-wing religious parties and their false propagations about socialism among the common people have led the masses to complete ignorance about the entire concept. Many students in Pakistan, who have been barred from taking part in politics due to the abolishment of student unions and realize the grave danger that the growing autocracy in Pakistan poses, have started marching on the streets for their political rights against the centuries old feudalism and status quo ${ }^{1}$. With no strong leadership or support, a confused, yet desperately fierce idea of socialism in their minds, they march with red flags across their chests, echoing Faiz's immortal words-

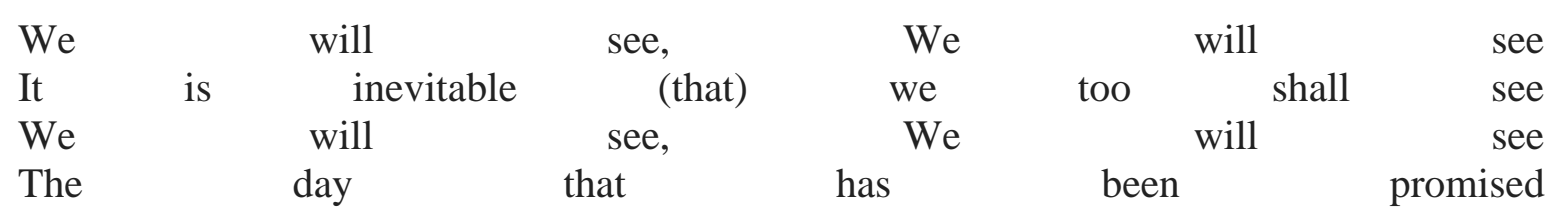


Communism- An Incomplete, Yet Unforgettable ...

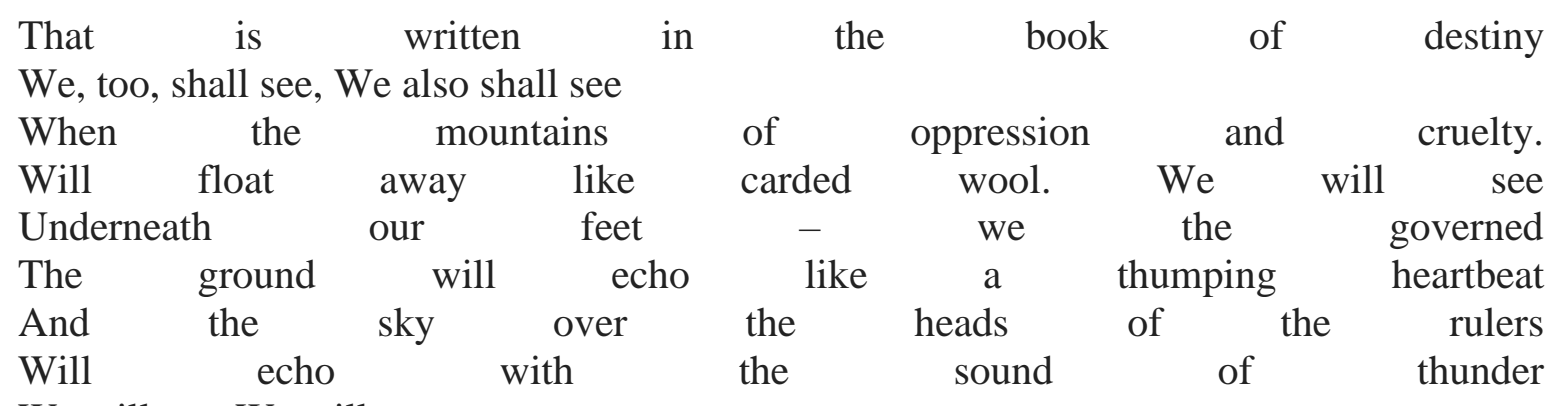

We will see, We will see 
Pak. Journal of Int'L Affairs, Vol 4, Issue 4 (2021) Communism- An Incomplete, Yet Unforgettable ...

\section{References}

Ahmed, I. (2010). The rise and fall of the Left and the Maoist movements in Pakistan. ."India Quarterly, n.d.: 251-265.

Ahmed, Salim. "Freedom Movement and Peshawar Conspiracy Cases." Pakistan Perspectives, 2016: 29-48.

CHOUDHARY, RATNADEEP. MN Roy, the Indian revolutionary who founded Mexican Communist Party. jan 25, 2019. https://theprint.in/theprint-profile/mn-roy-the-indianrevolutionary-who-founded-mexican-communist-party/182819/ (accessed 0110 , 2022).

Hamza, M. A. "The Rawalpindi Conspiracy Case: Myth or Reality - An Analysis." Muhammad Amir Hamza, 2006.

Jalil, Rakhshanda. "Revisiting the Legacy of Sajjad Zaheer, Founder of the All-India Progressive Writers' Association." Jamhoor, May 25, 2018.

Karat, Brinda. 100_year_of_formation-booklet. Formation of CPI, 1920, CPIM, November, 2019.

Maniruzzaman. " Crises in Political Development" and the Collapse of the Ayub Regime in Pakistan. ." The Journal of Developing Areas, 1971: 221-238.

Mariam Mufti, Sahar Shafqat, Niloufer Siddiqui. Pakistan's Political Parties: Surviving between Dictatorship and Democracy. Washington DC: Georgetown University Press, 2020.

Marx, K., \& Engels, F. "The Revolt in India. ." De Gruyter Akademie Forschung., 2019: 1073-1074.

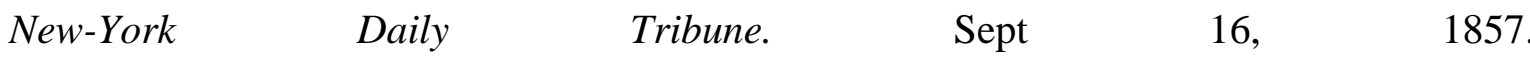
https://www.marxists.org/archive/marx/works/1857/09/16.htm (accessed $01 \quad 11$, 2022).

POET.ORG. n.d. https://poets.org/poet/faiz-ahmed-faiz (accessed 1 11, 2022). 
Pak. Journal of Int'L Affairs, Vol 4, Issue 4 (2021) Communism- An Incomplete, Yet Unforgettable ...

Rahim, Parvez. "NON-FICTION: THE FAILED COUP-MAKERS." NEWS PAPER. KHI: DAWN, AUG 11, 2019.

Shukla, P. K. " IMPERIALIST WAR TO PEOPLE'S WAR: Communist Strategy, 193942. I ." n Proceedings of the Indian History Congress., 1997: 555-563.

TFT. "student-resistance-1969." The Friday Times, Nov 22, 2019.

W. James, S.Roy. Foundations of Pakistan's political economy. Sage, 1992.

75th Anniversary of the Formation of the Communist Party of India. Jan-March 1984. https://www.cpim.org/marxist/1995_marxist_cpi_75_hks.htm (accessed 01 11, 2022). 